US WURK LXX (2021), p. 97

\title{
[1553] Linguistic Assertiveness to Contest Minorization: Observations from Small Interventions to Boost the Use of Frisian in Fryslân
}

\author{
Guillem Belmar Viernes
}

\begin{abstract}
As Belmar, van Boven \& Pinho (2019) pointed out, Frisians tend to quickly switch to Dutch in conversations in which their interlocutor either answers in Dutch or exhibits signs of struggling with Frisian. This accommodation is often seen as an act of politeness, but it also contributes to the minorization of, in this case, Frisian. Suay \& Sanginés (2010) argue that linguistic assertiveness needs to be considered in language promotion campaigns, as it aims to empower speakers to break away from these dynamics of diglossia.

In this paper we will present qualitative observations from two small interventions where 15 participants took part in Linguistic Assertiveness workshops designed to train them to trust receptive multilingualism and engage in bilingual conversations. The observations from these interventions show that politeness ideologies are an obstacle for the embrace of multilingual conversations, but positive attitudes and reports of positive experiences suggest that these can be contested. The results also suggest that further application of linguistic assertiveness - and the consequent embracing of bi-/multilingual conversations - may have a boosting effect on the use of the Frisian language in the province.
\end{abstract}

\section{Introduction}

Communicative interaction is known to be a stressful act to engage in, and this is especially true for speakers of minoritized languages. These often face uncertainty when engaging in new conversations, not knowing whether their language can or should be used in a given context. That is, language use in minoritized contexts is almost ubiquitously dominated by a dominant language, whose speakers use it comfortably and unconstestedly, regardless of the situation they find themselves in (Suay, 2019). Unfortunately, the same cannot be said for speakers of minoritized languages, whose language often becomes a marker of group membership, rather than the default tool of communication, and is therefore used almost exclusively with people known to - or that we assume can - speak the language.

Us Wurk 70 (2021), s. 97-117; https://doi.org/10.21827/6141dcbc15a43 


\section{US WURK LXX (2021), p. 98}

"For the most part, day in, day out, we are unfailingly polite. We grow up knowing our language isn't valued, that it's an inconvenience, that it's expensive, that it's asking too much. We never know in any given situation if someone's going to take against us in the workplace, in the street, in a pub, because we use it" (Hornsby, 2015, p. 15).

In minoritized contexts there is a strong association between ideologies of politeness and the forced accommodation to the dominant language whenever an interlocutor is not recognized as a speaker of the minoritized language (see, for instance, Trosset, 1986). Speakers of minoritized languages switch to the dominant language to save face (Brown \& Levinson 1978). By accommodating to the dominant language, speakers of minoritized languages save their own positive face, and make sure to not threaten the negative face of their interlocutors. In other words, speakers of minoritized languages design their utterances with a default dominant language speaking audience in mind (see Bell, 1984, on audience design).

This sort of inferiority complex that most speakers of minoritized languages have long interiorized is at the base of their apparent unwillingness to use the language with strangers. This automatic switch to the dominant language, also known as the rule of linguistic convergence, has long been described and identified as one of the main obstacles for the revitalization of languages such as Catalan (Boix 1993; Gibert, 2010; Junyent et al., 2011; Suay, 2019; Belmar, 2021). This unquestioned accommodation to the dominant language is not just a barrier for speakers of minoritized languages to express themselves in their own languages in as many contexts as possible (Belmar, 2019). This switch ensures that speakers of the dominant language barely hear the minoritized language, which is hidden away, preventing anyone else from familiarizing themselves with it (Belmar \& Pinho, 2020a). Discussing the Frisian context, Wolf (2013) wrote that: komt in net-sprekker in sprekker tsjin, dan krijt er de lijerige taal net te hearren (...) sa wurdt de lijerige taal stadichoan in groepstaaltsje foar ynwijden [when a non-speaker comes across a speaker, he does not hear the suffering language (...) thus, the suffering language gradually becomes an in-group language].

In some minoritized contexts, however, the dominant and the minoritized languages are closely related, and speakers of the former can generally understand basic conversations in the latter without much of an effort. Semicommunication (or semi-understanding) (Haugen, 1996; see also Braunmüller \& Zeevaert, 2001; Zeevaert, 2007) postulates that for communication to be successful, participants do not need to share the exact same language. In fact, Haugen (1996) goes as far as to state that "despite the growing loss 


\section{US WURK LXX (2021), p. 99}

of efficiency in the communication process as language codes deviate, it is often astonishing how great a difference speakers can overcome if the will to understand is there" (p. 280). Indeed, the attitude towards the other language seems to be a key factor for receptive competence or receptive multilingualism (see Gooskens, 2007). This receptive competence is expected to foster plurilingual communication (Lüdi, 2007), even conversations where participants speak different languages (Blees, Mak \& ten Thije, 2014; see also ten Thije \& Zeevaert, 2007; Beerkens \& ten Thije, 2011; Rehbein, ten Thije \& Verschik, 2012), a possibility for communication in multilingual contexts which embraces minoritized languages (Belmar \& Pinho, 2020a).

Thus, when accommodation takes places with interlocutors that do understand the minoritized language, it can be seen as an othering act, a marker of not belonging to the minoritized community. This has been found to have extremely detrimental effects on the motivation and attitudes of learners of Frisian (Belmar at al., 2019; Belmar, 2019). In addition to these minorization dynamics, one's decision to use one's own minoritized language is often based on assumptions of speakerhood which are mapped onto assumptions of ethnic and racial background. This often leads speakers of minoritized languages to use the dominant language by default with racialized members of their communities (Belmar, 2021).

There is, however, no objective argument to keep Frisian 'hidden' from Dutch speakers. In their recent paper on the intelligibility of Frisian for Dutch native speakers, Belmar \& Pinho (2020b) found out that the intercomprehension between these two languages seems to be as high as 75$80 \%$, which is far more than Swarte, Hilton, \& Goosken's (2013) suggestion of a $38 \%$ of intercomprehension needed to understand directions. In other words, Frisian and Dutch seem to set the perfect stage for receptive multilingualism, and Belmar \& Pinho (2020b) suggest that the province should "enact strategies to empower Frisian speakers to use their language, also in conversations with Dutch speakers" (p. 125) in order to break the current diglossic situation. In other words, linguistic assertiveness (Suay \& Sanginés, 2010) is essential to the re-framing of linguistic practices into a truly plurilingual habitus (Gogolin, 2002) that includes the autochthonous minoritized languages.

This paper reports on the qualitative observations of a preliminary study made during two small interventions (workshops) on linguistic assertiveness and bilingual conversations carried out in the province of Fryslân during May 2019. The aim of these interventions (workshops) was to assess the 


\section{US WURK LXX (2021), p. 100}

potential of larger initiatives to change the linguistic attitudes that prevent Frisian speakers from using their language in conversations with Dutch speakers. Section 2 provides a brief account of the context of Frisian, followed by a discussion on language assertiveness and politeness ideologies in section 3. Section 4 provides a detailed description of the workshops, the materials, and the participants in these interventions. The results are presented thematically in section 5 and illustrated with quotes taken from the participants' pre- and post-workshop questionnaires. Finally, the conclusion contains an overview of the main discussion topics of this article, as well as some suggestions should linguistic assertiveness workshops be made part of language promotion activities in Fryslân.

\section{The language context}

Frisian -also known as West Frisian, to distinguish it from North Frisian and Saterland Frisian - is a minoritized Germanic language spoken mainly in the province of Fryslân, as well as in some neighboring villages in the province of Groningen, in the Netherlands. (West) Frisian and Dutch are not the only languages spoken in the province. Other language varieties found in the province are the Low Saxon varieties of Stellingwerfs and Westerkwartiers, forms of Frisian that diverge quite a lot from standard Frisian such as Hylpers, as well as the mixed varieties of Dutch and Frisian such as Bildts (spoken in Het Bildt, in the Waadhoeke municipality), and those commonly referred to as City Frisian (Stadfries or Stedsk).

With about half a million speakers $(485,000)$, Frisian is the native language of about $61 \%$ of the population (Klinkenberg, Jonkman \& Stefan, 2018). However, the attitudes towards the language remain largely negative (Ytsma, 1995; Ytsma, 2007; Hilton \& Gooskens 2013; Belmar, 2018; 2019), which in turn makes the language less visible to non-speakers (see Wolf, 2013) and poses a challenge for language learners (Belmar et al., 2019). Previous literature has established the link between negative attitudes and perceived 'difficulty', 'foreignness' of a language (see Wolff, 1959; Giles \& Niedzielsky, 1998), a link which has been reported for Frisian as well (Belmar, 2018; 2019).

\section{Linguistic assertiveness, politeness, and saving face}

Suay \& Sanginés (2010) suggest linguistic assertiveness as an exercise which speakers of minoritized languages can practice in order to stop the minorization circle (see also Belmar \& Pinho, 2020a, p. 143). Suay (2016) 


\section{US WURK LXX (2021), p. 101}

describes it as a "coherence act", exercising your rights rather than defending them in elaborate speeches. By using your minoritized language to start any communicative interaction which you may engage in - that is, by using it as the default tool of communication -, you are defending your own right to speak it. And yet Suay \& Sanginés (2010) do not suggest that you should coerce your interlocutor to use this language, nor do they suggest that you stick to this language regardless of how (un)successfully your communicative exchange is unfolding. On the contrary, they advocate for acknowledging the right of your interlocutors to speak whatever language they prefer, and they admit that there are situations in which one may have to switch to the dominant language to ensure communication.

The reason why this switch may be necessary in certain contexts is because societal bilingualism rarely - if ever - is horizontal. Societal bilingualism often ends up in diglossia, or the situation where two languages coexist and are used in the same setting, but under different circumstances (see Baetens, 1986; Yuko \& Kenji, 2004). This specialization of functions for each variety determines the appropriateness of either variety for a set of situations with few occasions for overlapping (Ferguson, 1959). This differentiation is, in fact, maintained because speakers of the minoritized language internalize that using their language in the 'wrong' situation is rude. In other words, accommodation to the dominant language is conceptualized as a face-saving strategy (Brown \& Levinson, 1978), whereby speakers of minoritized languages save their positive face - i.e., the desire of being liked and approved -, while they avoid threatening the negative face of their interlocutors - i.e., the desire of being and acting as one pleases without obstacles.

In this frame, the minoritized language is seen as an obstacle for the 'normal' - or unmarked - use of the dominant language, as speakers of minoritized languages internalize early on a link between politeness and language choice. However, it is important to highlight that by insisting on the use of the minoritized language, speakers are actually contributing to raise language awareness. This is said to stimulate curiosity about language (Hélot, 2012), and perhaps even kickstart the motivation to learn the language (Belmar et al., 2019).

In fact, Suay \& Sanginés (2010) suggest that there are three types of speakers of minoritized languages: a) proactive speakers, who start the interaction in the dominant language; b) reactive speakers, who start in the minoritized language but switch to the dominant language as soon as they perceive the other person is struggling or if the other person answers in the 


\section{US WURK LXX (2021), p. 102}

dominant language; and c) resistant speakers, who insist in using the minoritized language and only switch to the dominant language when explicitly asked to. Note here that the authors do not suggest speakers of minoritized languages have to do away with all rules of accommodation or politeness, rather they should acknowledge their interlocutor and let them decide if a switch is at all needed. Speaking your own minoritized language, thus, is not rude. What is rude is to assume unknowingly that your interlocutor does not understand you.

\section{The workshops}

The study consisted of two two-hour-long workshops targeting two groups from different backgrounds: one group of language volunteers from Afûk ${ }^{1}-$ who regularly engage on promotion campaigns for Frisian -, and one group of employees from the Waadhoeke Gemeente - who, regardless of their language background, have shown some interest in improving Frisianlanguage costumer service at the local council. The aim of these two workshops was to assess how these two groups responded to a small intervention on linguistic assertiveness as a tool to boost the use of Frisian in the province of Fryslân. The workshops were designed in collaboration with Afûk and based on work from Suay (2016) and Suay \& Sanginés (2010), and they were carried out in Frisian by a professional from Afûk. A researcher from the University of Groningen was present at the first workshop.

Table 1. Participants

\begin{tabular}{lll} 
Participant & Volunteer or Employee & Mother tongue(s) \\
\hline P1 & V & Frisian \\
P2 & V & Frisian \\
P3 & V & Frisian \\
P4 & V & Frisian \\
P5 & V & Frisian
\end{tabular}

1. Afûk is a non-profit organization whose main aim is the creation of materials in and about Frisian, as well as the promotion of the language. 
US WURK LXX (2021), p. 103

$\begin{array}{lll}\text { P6 } & \text { V } & \text { Frisian } \\ \text { P7 } & \text { V } & \text { Frisian } \\ \text { P8 } & \text { V } & \text { Frisian-German } \\ \text { P9 } & \text { V } & \text { Frisian } \\ \text { P10 } & \text { E } & \text { Frisian } \\ \text { P11 } & \text { E } & \text { Bildts } \\ \text { P12 } & \text { E } & \text { Dutch } \\ \text { P13 } & \text { E } & \text { Frisian } \\ \text { P14 } & \text { E } & \text { Frisian-Franekers } \\ \text { P15 } & \text { E } & \text { Frisian }\end{array}$

Out of a total of 15 participants, 13 claimed Frisian to be their mother tongue (one participant reports both Frisian and German; with another participant reporting both Frisian and Franekers). One participant claimed Bildts as their mother tongue and, lastly, one of the participants reported Dutch as their mother tongue.

Table 2. Naming convention for participants

\begin{tabular}{|l|l|}
\hline $\mathrm{P}$ & Participant \\
\hline $1 / 2 / 3 \ldots$ & Number of participant \\
\hline $\mathrm{E} / \mathrm{V}$ & Employee / Volunteer \\
\hline $\mathrm{F} / \mathrm{D} / \mathrm{N} / \mathrm{B}$ & Mother tongue $^{3}$ \\
\hline
\end{tabular}

The workshops began with an introduction and the participants were given a pre-workshop form to fill in. After that, a toolbox was passed around and the participants had to take one object from it. Once they all had taken something, the instructor would ask each participant what they picked, why they did so, and in what ways that particular tool related to their relationship

2. Franekers is the name of the City Frisian variety of the town of Frjentsjer / Franeker.

3. F-Frisian / Franekers; D - German; N - Dutch; B - Bildts 


\section{US WURK LXX (2021), p. 104}

with their mother tongue. This led to a conversation sharing experiences in which the participants had to change to another language (for the most part, Dutch) and a group reflection on why that happened and how that made them feel.

After a short break, the instructor shortly introduced the notion of linguistic assertiveness (Suay \& Sanginés, 2010) as well as research done into intelligibility between Dutch and Frisian (Belmar \& Pinho, 2020b). This presentation aimed at providing them with some tools to practice linguistic assertiveness in Fryslân, linking their own experiences with experiences from other contexts (Suay \& Sanginés, 2010), academic theories, statistics from the province of Fryslân (Provinsje Fryslân, 2015), and research on the effect which the automatic switch to Dutch has on the motivation of learners of Frisian (Belmar et al., 2019). The workshop ended with a discussion on the ways in which linguistic assertiveness can be applied to our everyday lives and the possible impact this could have on the use of Frisian and Bildts. After the workshop, participants were sent a post-workshop questionnaire to fill in.

This paper presents an analysis of the observations and the answers to the open-ended questions of the pre- and post-workshop questionnaires. These open-ended questions were agreed upon among the researcher, the instructor of the workshop, as well as language promotion specialists at Afûk; and reflected areas of inquiry identified in previous research. Belmar (2018; 2019) identified the low use of Frisian by new speakers at the workplace, an area which had not been included in the previous report by the province (Provinsje Fryslân, 2015) - although it does appear in the more recent and much more complete report by Varkevisser and Walsweer (2018).

This finding, together with the observations and the experience of language promotion specialists, are the rationale behind the open-ended questions in the pre-workshop questionnaire: a) How many colleagues do you have?; b) With how many of them do you speak Frisian?; and c) Can you explain to us why you don't speak Frisian with some of your colleagues? Finally, the open-ended questions in the post-workshop questionnaire were designed to find out whether the participants had put in practice what they had learned in the workshop, as well as to elicit their attitudes towards linguistic assertiveness and receptive multilingualism. These were based on the expectation that participants would report some level of engagement with multilingualism, awareness of mutual intelligibility (Belmar \& Pinho, 2020b), and resistance to automatic language shift (Suay \& Sanginés, 2010) which can be interpreted as an othering device 


\section{US WURK LXX (2021), p. 105}

(Belmar et al., 2019). The questions were: a) Have you had a bilingual conversation in the last two weeks?; b) If so, how did it go? How did the other person react?; c) If not, what stopped you? (Frisian wording of the questions available in the annex).

\section{Results}

This section presents and analyzes some quotes from the open-ended questions included in the post-workshop questionnaire that the participants had to answer. The quotes have been translated into English by the researcher, and the originals in Frisian/Dutch can be found in the appendix.

"It was a nice and cozy evening"-Satisfaction with the workshop

The participants expressed satisfaction with the content of the workshop and, in particular, how thought-provoking it had been. They all actively engaged in the activities and discussions, and they all seemed very enthusiastic about the ideas presented, even those who had not put them into practice yet.

[P13EF] This has not (yet) changed from last week's workshop (...) if people tell me that I can (continue) speaking Frisian, then I will try that. [Q1]

Most importantly, several participants reported that they had observed a change not only in their own attitude and determination to speak Frisian, but also noticing how people may understand Frisian even when you would assume that they do not. One participant even exclaimed how amazed they were at their newfound determination to speak Frisian after the workshop.

[P10EF] This week the question came up I asked someone if she understood Frisian, because I thought maybe she came from outside of Fryslân. She said she understood, but she did not speak. Then I said that I would speak in Frisian. [Q2]

[P8VFD] I must say that even just being at the workshop has made me more determined to use Frisian (...) That an evening workshop already gets this from me, that is amazing. [Q3]

"(...) and then people also begin to switch to Frisian" - Receptive Multilingualism and Linguistic Assertiveness in Practice

Plenty of research shows that comprehension between two closely related linguistic varieties can happen without the need of actively learning the 


\section{US WURK LXX (2021), p. 106}

other language (e.g., De Vries, 2010; Belmar \& Pinho, 2020b). In fact, participants report that non-Frisian speakers often understand them perfectly, even making connections to other minoritized varieties spoken in the Netherlands, such as Limburgish.

[P4VF] My yoga instructor speaks Dutch. She understands me perfectly. [Q4]

[P1VF] Yes, she says, Frisian is really very similar to Limburgish, so it is not difficult for me. [Q5]

In addition, Suay \& Sanginés (2010) suggest that by actively asserting the minoritized language - i.e., by using it as the default language -, speakers of minoritized languages may trigger speakers of dominant languages to try speaking the minoritized language. Not only that, but raising language awareness (see Hélot, 2012) would also be another byproduct of practicing linguistic assertiveness. This language awareness leads to discussions on language in the province, and even in some cases to a change in other people's attitudes. One participant explains how they started speaking more Frisian in their daily lives and how that even led their Dutch-speaking housemates to speak more Frisian. And just as importantly, a Dutchspeaking participant reports how happy their interlocutor was when they realized they could speak Frisian.

[P1VF] (...) they even speak dialect. We just had a nice chat about language and about Fryslân. [Q6]

[P8VFD] It started because my Dutch-speaking housemates realized I kept speaking Frisian (...) At one point even they found themselves speaking Frisian and they also had the intention to speak Frisian even more. [Q7]

[P12EN] She was glad that she could speak Frisian. [Q8]

"Because they speak Dutch, I am afraid that they won't understand me at all" - Fear of not being understood

But, what factors prevent Frisian speakers from engaging in these multilingual conversations? Most of the participants expressed that the primary reason preventing them from using Frisian with some of their colleagues was their fear to not be understood. This fear was expressed both in person during the workshops and in writing on their questionnaires, and it is even explicitly linked to intergenerational transmission: "our father and mother 


\section{US WURK LXX (2021), p. 107}

did that too". In other words, participants believed that by speaking Frisian they could potentially exclude themselves from their colleagues.

[P13EF] (...) I also still remember that as a child I also switched from one to the other language. Our father and mother did that too. [Q9]

[P6MF] We just have a new director, who does not understand Frisian (yet). [Q10]

[P15EF] The colleagues are not Frisian speakers. [Q11]

In fact, research suggests that language attitudes in Fryslân only reinforce this perceived need of switching to Dutch when addressing (assumed) nonFrisian speakers (Ytsma, 1995; Ytsma, 2007; Hilton \& Gooskens, 2013; Belmar, 2018; Belmar et al., 2019; Belmar, 2019). Oftentimes, these assumptions may even lead to Frisian speakers themselves using Dutch among them until they realize they're both speakers of Frisian.

[P2VF] I heard that the other one had a Frisian accent and I suggested speaking only Frisian. She was very happy and excited. [Q12]

"I don't do it out of politeness" - Accommodation as face-saving

As part of the dynamics of minorization to which minoritized languages are subject, and intrinsic to the diglossia, the use of the minoritized language in a context other than those deemed appropriate is considered rude, as Dutch is the main language in most public situations. It is, in fact, considered highly impolite to use Frisian when the interlocutor replies in Dutch, regardless of their ability to understand Frisian. Accommodation to the dominant language is, therefore, a strategy to save face, a behavior whereby the speakers of the minoritized variety sacrifice part of who they are to fulfill the desire to be accepted, all the way prioritizing the ease of their interlocutors. This, in fact, is something that participants mentioned a lot in their post-workshop report when asked what were the reasons that may have stopped them from engaging in bilingual conversations with non-Frisian speakers.

[P8VFD] Still afraid that people would find it impolite... sorry. [Q13]

[P6MF] I find it impolite; Dutch is the main language in most public situations. [Q14]

[P11EB] In my opinion, this has to do with politeness. I do not want them to not be able to understand me. [Q15] 


\section{US WURK LXX (2021), p. 108}

However, research on learners of minoritized languages, for example, has shown that such a practice can have extremely negative effects on their motivation, even acting as an 'identity control mechanism' (O'Rourke \& Ramallo, 2013, p. 290) which can easily lead to frustration and may discourage any learners from speaking the language (O'Rourke \& DePalma, 2016, p. 4; see also Belmar et al., 2019). It seems, therefore, that promotion and revitalization campaigns should target ideologies of politeness to convince speakers of minoritized languages to stop assuming that their interlocutors cannot understand them, and to stop linking language choice to politeness. Taking into account Suay \& Sanginés (2010), revitalization campaigns should aim at turning proactive speakers into resistant speakers, and the use of the minoritized language made commonplace and the default language in which speakers start interactions.

[P4VF] I ask first if they understand Frisian. If not, then I speak Dutch. [Q16]

[P9VF] If I notice that the other person understands Frisian, then I do my best to keep speaking Frisian. But if they do not understand, then I immediately switch to Dutch. [Q17]

"I find it appropriate and easier to have a conversation in the same language" - The effects of politeness and monolingual ideologies on the use of minoritized languages

Despite the overall positive experiences that the participants shared, some participants also reported struggling with the very idea of having a conversation in two different languages. For some, it is almost 'unnatural' to consciously use different languages in one communicative exchange —even though intelligibility has always been at the core of acceptability of conversations, rather than sharing the same named code. In fact, both Frisian and Dutch are highly intercomprehensible (Belmar \& Pinho, 2020b), code-switching is already a fairly commonplace practice in Fryslân, and translanguaging strategies are becoming increasingly popular in the education system in the province (see Duarte \& Jellema, 2017; Duarte \& Günter-van der Meij, 2018; Duarte, 2019).

[P9VF] But I do have walls where it is very difficult to keep speaking Frisian when the other person speaks Dutch or City Frisian. [Q18]

[P14EFF] I find it more pleasant to speak the same language, which reduces the distance between interlocutors, for me. I adapt to this, and I feel comfortable with it. [Q19] 


\section{US WURK LXX (2021), p. 109}

The perceived need to accommodate one's speech to the highest prestige variety involved in the conversation is a sign of diglossia, and it is something that should be tackled in revitalization campaigns. This is not to say that speakers do not have other reasons to switch, and questioning the creative ways in which speakers deploy their linguistic repertoire is not the goal of untangling these ideologies of politeness and these minorization dynamics. Rather, it is about raising awareness of an external factor that is influencing the way in which they interact with the world and giving them the tools to engage with their interlocutors in whatever language they freely choose to do so.

In fact, the experiences of some of the participants show that, since all the Germanic varieties currently spoken in the province of Fryslân are closely related and mutually intelligible to a certain degree (see De Vries, 2010; Belmar \& Pinho, 2020b), conversations in Frisian and Dutch - and also Bildts and/or City Frisian - are not only possible, but they are very often extremely positive.

[P8VFD] At the station in Ljouwert, I started in Frisian and the woman at the coffee shop replied in Ljouwerters (also nice) [Q20]

[P1VF] Awesome (...) I liked speaking Frisian. [Q21]

[P11EB] Good, it makes the conversation just easier. [Q22]

\section{Conclusion}

The results of this study hint at some positive effects that may come about with the implementation of Linguistic Assertiveness Workshops in Fryslân. Participants agreed on the usefulness of the workshop they received, be it as a therapeutic experience for most Frisian or Bildts speakers who took part in the project or as a tool with the potential to boost the use of these languages in the province. Despite this, it is important to highlight that the attitudes observed among participants cannot be generalized to possible future participants with a wider range of experiences and linguistic backgrounds. Nevertheless, the participants' positive review of the workshop suggests that Linguistic Assertiveness can be integrated in future language promotion activities in the province, and that such workshops may have a place among these activities.

In addition, this study also showed the participants' reactions to the notion of Receptive Multilingualism and Linguistic Assertiveness, which are highly important should another iteration of these workshops take place. 


\section{US WURK LXX (2021), p. 110}

The issues that seem to be preventing Frisian speakers from using their language with strangers are mainly a fear of not being understood and a believe that accommodation to the dominant language is a sign of politeness. The first reason has largely been documented as preventing speakers of minoritized languages from using their language (see, for example, Belmar, 2020, on the use of minoritized languages on social media) and may well be attributed to audience design strategies (see Bell, 1984). In other words, the status of the dominant language as the 'unmarked', default language of wider communication makes speakers favor it over the use of minoritized languages, which are often considered just a means to communicate with a very specific audience.

As for accommodation as a sign of politeness, it has long been argued that speakers of minoritized languages switch to the dominant language to be polite with their interlocutor (see, for instance, Trosset, 1986), to save face. This ideology can be seen in the results of this study, as several participants expressed feeling uncomfortable with bilingual conversations because it is impolite to not accommodate to the dominant language. Nevertheless, more recent research on new speakers of minoritized language suggests that such a strategy may actually be perceived by majority language speakers as having a barring effect from the minoritized language (see, for instance, O'Rourke \& Ramallo, 2013; O'Rourke \& DePalma, 2016; Belmar et al., 2019), that is, a practice that marks them as outsiders and prevents them from ever familiarizing themselves with the minoritized language.

Suay \& Sanignés' (2010) suggestions for linguistic assertiveness indicate that these ideologies should be addressed in revitalization campaigns, with workshops that could turn proactive speakers into resistant speakers, thus breaking the diglossic patterns observed in the Frisian context. It is worth remembering that Suay \& Sanginés (2010) do not advocate for the indiscriminate use of the minoritized language in all contexts and all interlocutors with no consideration towards the amount of information that is successfully conveyed. On the contrary, they advocate for the empowerment of speakers of minoritized languages to treat their languages as unmarked in their social interactions, and at the same time they admit that there are situations in which one may have to switch to a dominant language to ensure communication, be it for personal interest - the need to convey a message - or politeness - deference towards one's interlocutor.

Finally, some of the participants showed resistance to linguistic assertiveness or even the idea of using two languages in a single communicative 


\section{US WURK LXX (2021), p. 111}

exchange. It is the author's suggestion that future iterations of these interventions should include some training on multilingual practices and translanguaging in the workshops, which could better equip the participants in understanding that their conversations most likely already feature multilingual lexical choices, and could convince them of letting go of an ideal monolingualism that may not be as realistic as one would expect.

In fact, the results of this study signal the importance of the promotion of bilingual conversations for the promotion of Frisian in the province of Fryslân, especially in the cities. According to Belmar \& Pinho (2020b), Dutch speakers can understand Frisian to an extremely high degree somewhere between 70 and $80 \%$ which makes them wonder what is stopping the province from making a more widespread use of the language. By increasing the number of tokens in Frisian visible in the streets of Fryslân, as well as the use of spoken Frisian in public events (be it alongside Dutch or exclusively) the prestige of the language can easily be increased all the while improving the knowledge of Frisian some Dutch speakers may have and securing a safe space where both languages can be used equally. The Linguistic Assertiveness workshops presented in this paper can be used as a tool to raise awareness among both Frisian and Dutch speakers, empowering the former and engaging the latter to achieve a more egalitarian bilingualism where both languages may be the 'default' language in any communicative exchanges.

Acknowledgments: Gerbrich de Jong (RUG) for translating all the research material into Frisian; Mirjam Vellinga (Afûk) for helping set up this project from the beginning and taking care of the workshops; and Goffe Jensma (RUG) for his support.

University of California, Santa Barbara guillem.belmar@gmail.com 


\section{US WURK LXX (2021), p. 112}

\section{REFERENCES}

Baetens, B.H. (1986). Bilingualism: basic principles. Clevedon: Multilingual Matters.

Beerkens, R. \& ten Thije, J.D. (2011). Receptive Multilingualism in the Dutch-German Border Area. In J.N. Jørgensen (Ed.), A Toolkit for Transnational communication in Europe - Copenhagen studies in bilingualism, 64, 102-140.

Bell, A. (1984). Language style as audience design. Language in Society, 13(2), 145-204.

Belmar, G. (2021). Glocalization, (un)markedness and sustainable multilingualism: Catalonia, the de-territorialisation and de-ethnicization of Catalan. In Steven Byrne (ed.), El Procés: Identity and Nation in $21^{\text {st }}$ Century Catalonia (pp. 265-283). Cambridge: Cambridge Scholars Publishing.

Belmar, G. (2020). Digital presence and language revitalization: attitudes towards and use of minority languages on social media. In Lydia Schiriha (ed.), Comparative studies in Bilingualism and Bilingual Education (pp. 199-216). Cambridge: Cambridge Scholars Publishing.

Belmar, G. (2019). Attitudes and language use of (potential) new speakers of a minoritized language: the case of adults learning West Frisian in formal courses. Sustainable Multilingualism, 15(2), 70-88.

Belmar, G. (2018). New speakers of a minoritized language: motivation, attitudes and language use of 'nije sprekkers' of West Frisian. Master's thesis, Rijksuniversiteit Groningen.

Belmar, G., van Boven, C. \& Pinho, S. (2019). Why do adults decide to learn a minority language? A study of the motivation(s) of potential new speakers of West Frisian. Sustainable Multilingualism, 14(1), 138-151.

Belmar, G. \& Pinho, S. (2020a). Multilinguismo receptivo: um aliado das línguas menorizadas. O que é que o mirandês pode aprender da experiência frísia? Études romanes de Brno, 41(1), 141-157.

Belmar, G. \& Pinho, S. (2020b). 'Kinsto it Frysk ferstean?' Intelligibility of West Frisian for Dutch native speakers. Dutch Journal of Applied Linguistics, 9(1/2), 109-131.

Blees, G.J., Mak, W.M. \& ten Thije, J.D. (2014). English as a lingua franca versus lingua receptiva in problem-solving conversations between Dutch and German students. Applied Linguistics Review, 5(1), 173-193.

Boix, E. (1993). Triar no és trair. Identitat i llengua en els joves de Barcelona. Barcelona: Edicions 62. 


\section{US WURK LXX (2021), p. 113}

Braunmüller, K. \& Zeevaert, L. (2001). Semikommunikation, rezeptive Mehrsprachigkeit und verwandte Phänomene. Eine bibliographische Bestandsaufnahme. Arbeiten zur Mehrsprachigkeit - Folge B, nr. 19, Universität Hamburg.

Brown, P. \& Levinson, S. (1978). Universals in Language Usage: Politeness Phenomena. In E. Goody (ed.), Questions and Politeness: Strategies in Social Interaction (pp. 56-310). Cambridge: Cambridge University Press.

De Vries, T. (2010). De fersteanberens fan it Frysk foar dialektsprekkers. Us Wurk, Tydskrift foar Frisistyk / Journal of Frisian Studies, 59, 132-157.

Duarte, J. (2019). Translanguaging in mainstream education: A sociocultural approach. International Journal of Bilingual Education and Bilingualism, 22(2), 150-164.

Duarte, J. \& Günther-van der Meij, M. (2018). A holistic model for multilingualism in education. EuroAmerican Journal of Applied Linguistics and Languages, 5(2), 24-43.

Duarte, J. \& Jellema, K. (2017). Translanguaging yn de trijetalige skoalle. Leeuwarden: NHL University of Applied Sciences.

Ferguson, C.A. (1959). Diglossia. Word, 15, 325-340.

Gibert, Q. (2010). La norma de convergència del català al castellà. Llengua Nacional, 70, 12-13.

Giles, H. \& Niedzielski, N. (1988). 'Italian is beautiful, German is ugly'. In L. Bauer \& P. Trudgill (eds.), Language myths (pp. 85-93). London: Penguin.

Gogolin, I. (2002). Linguistic and cultural diversity in Europe: A challenge for educational research and practice. European educational research journal, 1, 123-138.

Gooskens, C. (2007). The contribution of linguistic factors to the intelligibility of closely related languages. Journal of Multilingual and Multicultural Development, 28(6), 445-467.

Haugen, E. (1996). Semicommunication: The language gap in Scandinavia. Sociological Inquiry, 36(2), 280-297.

Hélot, C. (2012). Linguistic diversity and education. In M. Martin-Jones, A. Blackledge \& A. Creese (Eds.), The Routledge Handbook of Multilingualism (pp. 214-231). New York: Routledge.

Hilton, N. \& Gooskens, C. (2013). Language policies and attitudes towards Frisian in the Netherlands. In C. Gooskens \& R. van Bezooijen (Eds.), Phonetics in Europe: Perception and Production (pp. 139-157). Frankfurt am Main: P.I.E.- Peter Lang. 


\section{US WURK LXX (2021), p. 114}

Hornsby, M. (2015). Revitalizing minority languages. New speakers of Breton, Yiddish, and Lemko. Basingstoke: Palgrave MacMillan.

Junyent, M. C., Monrós Marin, E., Fidalgo Piña, M., Cortès i Colomé, M., Comellas, P. \& Barrieras, M. (2011). Canvi de representacions lingüístiques de parlants al-loglots per contacte amb la situació lingüística catalana. Barcelona: Generalitat de Catalunya. Departament de Benestar Social i Família. Direcció General per a la Immigració.

Klinkenberg, E., Jonkman, R. \& Stefan, N. (2018). Taal yn Fryslân, de folgjende generaasje. Ljouwert / Leeuwarden: Fryske Akademy.

Lüdi, G. (2007). The Swiss model of plurilingual communication. In J.D. ten Thije \& L. Zeevaert (Eds.), Receptive multilingualism. Linguistic analyses, language policies and didactic concepts (pp. 159-178). Amsterdam: John Benjamins.

O'Rourke, B. \& DePalma, R. (2016). Language-learning holidays: what motivates people to learn a minority language? International Journal of Multilingualism, 14(4), 332-340.

O'Rourke, B., \& Ramallo, F. (2013). Competing ideologies of linguistic authority amongst new speakers in contemporary Galicia. Language in Society, 42(3), 287-305.

Provinsje Fryslân (2015). De Fryske taalatlas 2015. Fryske taal yn byld. Leeuwarden/Ljouwert: Provinsje Fryslân.

Rehbein, J. ten Thije, J.D., \& Verschil, A. (2012). Lingua receptive (LaRa) - remarks on the quintessence of receptive multilingualism. International Journal of Bilingualism, 16(3), 248-264.

Suay, F. (2016). Com incidir sobre els usos lingüístics? Una perspectiva psicològica. Presented at the 24 linguistics colloquium "La promoció de l'ús de la llengua des del sistema educatiu: realitats i possibilitats" at the University of Barcelona.

Suay, F. (2019). Com incidir sobre els usos lingüístics? Una perspectiva psicològica. In F. Xavier Vila i Moreno \& Emili Boix Fuster (eds), La promoció de l'ús de la llengua des del Sistema educatiu: realitats $i$ possibilitats (pp. 23-36). Barcelona: Edicions de la Universitat de Barcelona.

Suay, F. \& Sanginés, D. (2010). Sortir de l'armari lingüistic: una guia de conducta per a viure en català. Barcelona: Angle Editorial.

Swarte, G., Hilton, N.H. \& Gooskens, C. (2013). Onderlinge verstaanbaarheid tussen Noord- en Westerlauwers Fries. Us Wurk. Tydskrift foar Frisistyk / Journal of Frisian Studies, 61, 21-46. 


\section{US WURK LXX (2021), p. 115}

Ten Thije, J.D. \& Zeevaert, L. (2007). Receptive multilingualism. Linguistic analyses, language policies and didactic concepts. Amsterdam: John Benjamins.

Trosset, C.D. (1986). The social identity of Welsh learners. Language in Society, 15(2), 165-191.

Varkevisser, N. \& Walsweer, A. (2018). It is mei sizzen net te dwaan: Rapport Taalplan Frysk. Ljouwert / Leeuwarden: Provinsje Fryslân.

Wolf, H. (2013). Wat makket it út oft it Frysk útstjert? Retrieved from: http://www.demoanne.nl/makket-it-no-ut-oft-it-frysk-utsjert/

Wolff, H. (1959). Intelligibility and inter-ethnic attitudes. Anthropological Linguistics, 1, 34-41.

Ytsma, J. (1995). Frisian as first and second language. Leeuwarden/ Ljouwert: Fryske Akademy.

Ytsma, J. (2007). Language use and attitudes in Fryslân. In D. Lasagabaster \& A. Huguet (Eds.), Multilingualism in European bilingual contexts (pp. 144-164). Clevedon: Multilingual Matters.

Yuko, G.B. \& Kenji, H. (2004). Bilingualism and Second Language Acquisition. In T. Bathia \& W. Ritchie (Eds.), The Handbook of Bilingualism and Multilingualism (pp. 114-132). Singapore: Blackwell Publishing.

Zeevaert, L. (2007). Receptive multilingualism and inter-Scandinavian semicommunication. In J.D. ten Thije \& L. Zeevaert (Eds.), Receptive multilingualism. Linguistic analyses, language policies and didactic concepts (pp. 103-135). Amsterdam: John Benjamins. 
US WURK LXX (2021), p. 116

\section{ANNEX}

Open-ended questions in the pre-workshop questionnaire:

a) Hoefolle kollega's ha jo?

b) Mei hoefolle dêrfan prate jo Frysk?

c) Kinne jo taljochtsje wêrom't jo mei guon kollega's gjin Frysk prate?

Open-ended questions in the post-workshop questionnaire:

a) Ha jo de lêste twa wike in twatalige konversaasje hân?

b) Sa ja, hoe gong it? Hoe reagearre de oar?

c) Sa net, wat hâlde jo tsjin?

\section{Original quotes in Frisian/Dutch:}

[Q1] Dat is (noch) net feroare nei de workshop fan ferliene wike (...) as minsken by my sarijaan dat ik best Frysk prate (bliuwe) mai, dan sil ik dat besykje.

[Q2] Dizze wike kaam der wat praat fan doet ik ien frege oft se Frysk ferstie om't ik tocht dat de miskien fan bûten Fryslân kaam. Dyjinge sei sels dat se ' $t$ wol ferstie, mar net sels prate. Doe sei ik dat ik dat dan dwaan soe.

[Q3] Ik moat sizze dat allinich al it oanwêzich wêzen by de workshop, my al in stik skerper make hat om it Frysk te brûken (...) Dat ien workshopjûn dit al foarelkoar krijt, dat is dochs prachtich.

[Q4] Myn yoga dosint praat Nederlânsk. Hja ferstiet my prima.

[Q5] Ja, sei se, het Fries lijkt erg veel op het Limburg, dus het is net moeilijk voor mij.

[Q6] (...) sy prate sels dialekt. Hienen we samar in moai petear oer taal en oer Fryslân.

[Q7] It begûn Nederlânsktalige húgenoaten fan my al op te fallen dat ik Frysk troch praten bliuw (...) Op in stuit wie it safier dat se sels ek Frysk begûnen te praten mar ek de yntinsje hiene om mear Frysk te praten.

[Q8] Die wie bliied dat se Frysk prate koe.

[Q9] (...) Ik wit ek noch dat ik as bern ek skeakele fan de iene op de oare taal. Us heit en meme diene dat ek.

[Q10] We hawwe krekt in nije direkteur, dy't it Frysk (noch) net ferstiet.

[Q11] De collega's zijn niet friestalig. 


\section{US WURK LXX (2021), p. 117}

[Q12] Ik hearde oan 'e útspraak fan de oar dat dy in Fryske tongfal hie en stelde doe foar om mar Frysk te praten. Sy regearre bliid en optein.

[Q13] Dochs bang dat minsken it ûnfatsoenlik fine soenen... Spitich.

[Q14] Dat fyn ik ûnfatsoenlik, Nederlânsk is yn de meast publieke situaasjes de fuortaal.

[Q15] Voor mijn gevoel heft dit met fatsoen te maken. Ik wil niet dat zij mij niet kunnen verstaan.

[Q16] Ik freegje earst as hja Frysk ferstean. Se net dan praat ik wol Hollânsk.

[Q17] As ik merk dat de oar Frysk ferstiet, doch ik myn best om Frysk praten te bliuwen. Mar as se it net fersteane, dan skakelje ik daliks oer Nederlânsk.

[Q18] Mar ik haw wol muren dat ik dreech is om fol te hâlden om Frysk te praten as de oare Nederlânsk of stêdfries praat.

[Q19] Ik vind het prettiger om dezelfde taal te spreken, dat verkleint voor mij de afstand tussen de gesprekspartners. Ik pas mij hierin aan en voel mij hierbij meer op mijn gemak.

[Q20] (...) Op stasjon yn Ljouwert, begûn ik yn 't Frysk en de kofjefrou praatte wat Ljouwerters werom (ek leuk).

[Q21] Prima (...) Fûn it goed dat ik Frysk praat.

+[Q22] Goed, maakt de conversatie alleen maar gemakkelijker erop. 